Vet. Pathol. 12: 335-348 (1975)

\title{
Feline Infectious Peritonitis
}

\section{Proteins of Plasma and Ascitic Fluid}

\author{
M. Gouffaux, P.P. Pastoret, M. Henroteaux and A. Massip
}

Faculty of Veterinary Medicine, University of Liège, Brussels

\begin{abstract}
Electrophoreses of sera, plasma and ascitic fluids of cats with natural or experimental infectious peritonitis show important modifications. Special stainings of electrophoreses and chromatographic and immunoelectrophoretic technics characterized some of the modified proteins. In the experimental disease, fibrinogen, haptoglobin, transferrin, and probably orosomucoid are increased; in the natural disease, in addition to these modifications, the $\gamma$-globulins are strongly increased; the immunoglobulins found in the often abundant ascitic fluid belong to the IgG class. Increased proteins such as fibrinogen, haptoglobin and orosomucoid and decreased albumin are aspecific aspects of inflammatory processes, whereas hyperganmaglobulinemia appears in the course of immunological response. The rapid evolution of the experimental disease explains the fact that immunoglobulins do not increase.
\end{abstract}

In a previous paper [15], we described the first experimental transmissions of feline infectious peritonitis from clinically affected animals. The clinical, hematological and anatomopathological aspects and the wide geographical spread of the natural disease were stressed; since then, infectious peritonitis has been also reported in Australia [11, 28], Switzerland [20] and Germany [21].

In the present paper, some of the clinical and anatomopathological aspects of the experimental as well as the natural cases are described and compared with those previously reported.

\section{Materials and Methods}

The animals affected by natural disease (NOC) varied in age and sex. They were numbered from NOC 01 to 09 . At the last stage of the disease, serum, plasma, pleural and ascitic fluids were collected. After death, samples were taken for histopathological exami- 
Table 1 . Inoculations and results

\begin{tabular}{|c|c|c|c|c|c|c|}
\hline Cat & $\begin{array}{l}\text { Age } \\
\text { years }\end{array}$ & Sex & $\begin{array}{l}\text { Origin of } \\
\text { inoculums }\end{array}$ & $\begin{array}{l}\text { Nature and quantity } \\
\text { of inoculum }{ }^{1}\end{array}$ & $\begin{array}{l}\text { Date of } \\
\text { inoculation }\end{array}$ & Results² \\
\hline Exp. 10 & 5 & F & Noc 05 & $\begin{array}{l}\text { liver suspension in } \\
5 \mathrm{ml} \mathrm{PBS}\end{array}$ & $8 / 5 / 74$ & $\begin{array}{l}\text { dead of FIP } \\
\text { on } 29 / 5 / 74\end{array}$ \\
\hline Exp. 11 & 3 & M & exp. 09 & $\begin{array}{l}\text { organs suspension } \\
\text { in } 10 \mathrm{ml} \text { PBS }\end{array}$ & $8 / 5 / 74$ & $\begin{array}{l}\text { killed with } \\
\text { FIP on } 29 / 5 / 74\end{array}$ \\
\hline Exp. 12 & 8 & $\mathrm{~F}$ & exp. 08 & $\begin{array}{l}\text { liver suspension } \\
\text { in } 10 \mathrm{ml} \text { PBS }\end{array}$ & $8 / 5 / 74$ & $\begin{array}{l}\text { recovered from } \\
\text { the disease }\end{array}$ \\
\hline Exp. 13 & 1 & $\mathbf{F}$ & Noc 04 & $\begin{array}{l}\text { liver suspension } \\
\text { in } 10 \mathrm{ml} \text { PBS }\end{array}$ & $8 / 5 / 74$ & no sign of disease \\
\hline
\end{tabular}

nations. Liver, spleen, ascitic fluid and urine samples were aseptically taken and stored at $-20^{\circ} \mathrm{C}$ to obtain a stock of inoculation material. Soon after abdominal puncture, $5 \mathrm{ml}$ of ascitic fluid from cats NOC 06 and 09 were stored in five heparinized $(25 \mathrm{mg}$ heparin/ml) and five nonheparinized tubes, by pairs, respectively, at $-20,4,20,37$, and $56^{\circ} \mathrm{C}$ for $16 \mathrm{~h}$. All were then brought to $20^{\circ} \mathrm{C}$, examined, and submitted to agarose gel electrophoresis.

Four conventional cats (numbered exp. 10 to exp. 13) of various ages and sex and not previously treated were inoculated with infected organ suspensions in phosphate-buffered saline (PBS) (table I). Kanacilline ${ }^{\circledR}$ was added to the virulent material in order to give $5 \mathrm{mg}$ of kanamycin sulfate to each cat. Temperature was recorded each day, in the morning, from 2 days before the inoculation to the end of the disease. Two days before and every day after inoculation, blood samples were collected through the ear vein from fasting, tranquillized (Rompun ${ }^{\circledR}$ ) cats for a blood count; simultaneously, blood was taken by cardiac puncture to obtain serum and plasma. Soon after death, the same samples were taken as in natural cases.

Total proteins of sera, plasma, pleural and ascitic fluids were assayed by the biuret method; serum glutamic-oxalacetic and glutamic-pyruvic (SGOT, SGPT) were measured by the Sigma Chemical method [19].

Electrophoreses were performed on agarose plates in barbital buffer, $\mathrm{pH} 8.6$, ionic strength 0.075 , stained by amido-black for total proteins and by periodic acid-Schiff (PAS) for glycoproteins [22]. Fibrinogen was identified by comparison of serum and plasma electrophoreses. Haptoglobin was determined by hydrogen-peroxide and benzidine [9] after human hemoglobin was added. To determine the saturation capacity of the haptoglobin in hemoglobin, serum or ascitic fluid electrophoreses were performed with increasing amounts of hemoglobin (from 1 to $20 \mathrm{mg} / \mathrm{ml}$ ).

Immunoelectrophoreses were carried out in agarose gel (Immunoagaroslide, Millipore) in barbital buffer, $\mathrm{pH} 8.6$, ionic strength, 0.1. Goat serum against normal cat whole serum was supplied by Nordic Diagnostic (Tilburg, The Netherlands), and Dr. J.P. VAERMAN $[23,24]$ provided the rabbit sera against cat $\operatorname{IgG}_{1}$ and $\operatorname{IgG}_{2}, \operatorname{IgA}$ and $\mathrm{IgM}$, as well as rabbit serum against dog transferrine. 
Ten milliliters of ascitic fluid were clarified and then dialyzed against $2 \% \mathrm{NaCl}(\mathrm{w} / \mathrm{v})$ buffered with $0.02 \mathrm{M}$ Tris-HCl buffer, $\mathrm{pH} 8.0$, containing $0.1 \% \mathrm{NaN}_{3}$, and then eluted with the same buffer on a column (Pharmacia, Uppsala, Sweden; K 26/100) of Sephadex G-200 under a $40-\mathrm{cm}$ water pressure. The eluate was divided into five fractions that were concentrated prior to electrophoretic and immunoelectrophoretic analysis in agarose gel.

Twenty milliliters of ascitic fluid were dialyzed against $0.005 \mathrm{M}$ Tris- $\mathrm{HCl}$ buffer, $\mathrm{pH} 8.0$, and then layered over a column (Pharmacia; K 26/30) of diethylaminoethyl Sephadex A-50 balanced by the same buffer. The proteins eluted in this step form a first fraction. A second fraction results from the elution by a $0.04 \mathrm{M}$ Tris- $\mathrm{HCl}$ buffer, $\mathrm{pH} 8.0$; and a third one from the elution by a $0.04 \mathrm{M}$ Tris- $\mathrm{HCl}$ buffer, $\mathrm{pH} 8.0$, containing $1 \mathrm{M} \mathrm{NaCl}$. The three fractions were concentrated before electrophoretic and immunoelectrophoretic analysis in agarose gel.

The eluates were concentrated through ultrafiltration Millipore cells, with Pellicon PSAC membranes, under a pressure of $4 \mathrm{~kg} / \mathrm{cm}^{2}$.

Antiserum against cat IgG was prepared by intradermic inoculations of the rabbit with the second fraction obtained by ion exchange chromatography, emulsified in the complete Freund's adjuvant. The $\gamma$-globulins thus obtained were purified by $40 \%$ ammonium sulfate precipitation, then absorbed on the first elution fraction on Sephadex G-200 of the ascitic fluid.

\section{Results}

\section{Experimental Disease}

Two of the four inoculated cats (exp. 10 and 11) had a typical experimental disease (table I). The clinical evolution, hematological findings, body temperature, macroscopic and microscopic lesions corresponded to those previously described $[6,12,14,25]$. The duration of the experimental disease ranged from 2 to 3 weeks. The most important clinical findings were anorexia, weakness, and wasting; the first sign was a rise in body temperature on the second day; after a short remission, there was hyperthermia and, before death, strong hypothermia. The leukocyte count was usually elevated shortly after the onset of the fever. There was marked neutrophilia up to $90 \%$. The red blood cell count showed no significant modification. Each infected cat had less than $100 \mathrm{ml}$ of fluid in the peritoneal cavity and had diffuse fibrinous peritonitis. Discrete, white foci were obvious all over the liver and kidneys. Many foci of necrosis and neutrophilic infiltration of fibrinous exudate were found on the serosae, and within the parenchyma of the liver and kidneys. Germinative follicles of the spleen and abdominal lymph nodes were hypertrophied by accumulation of cellular debris, histiocytes, and neutrophils [15].

One cat (exp. 12) showed clinical, hematological and electrophoretic signs of an experimental disease until the 10th day, then everything returned 
Table II. Agarose gel electrophoreses;

values for normal plasma and plasma and ascitic fluid 20 days after inoculation

\begin{tabular}{llrrrrrrr}
\hline Origin & Units & Albumin & \multicolumn{1}{l}{$\alpha_{1}$} & \multicolumn{1}{l}{$\alpha_{2}$} & \multicolumn{1}{c}{$\beta_{1}$} & $\beta_{2}$ & $\gamma$ & $\begin{array}{c}\text { Total } \\
\text { protein }\end{array}$ \\
& & & & & & & & \\
\hline Plasma exp. 10 & $\%$ & 45.00 & 8.50 & 10.00 & 13.50 & 8.00 & 1.50 & 100 \\
$\quad$ before inoculation & $\mathrm{g} / \mathrm{dl}$ & 3.06 & 0.58 & 0.68 & 0.92 & 0.55 & 1.02 & 6.88 \\
Plasma exp. 10 & $\%$ & 29.23 & 12.31 & 18.46 & 13.85 & 18.46 & 7.69 & 100 \\
20 days & $\mathrm{g} / \mathrm{dl}$ & 3.10 & 1.30 & 1.96 & 1.47 & 1.96 & 0.82 & 10.60 \\
after inoculation & & & & & & & & \\
Ascitic fluid exp. 10 & $\%$ & 35.19 & 9.26 & 20.37 & 11.11 & 7.41 & 16.67 & 100 \\
20 days & $\mathrm{g} / \mathrm{dl}$ & 2.01 & 0.53 & 1.16 & 0.63 & 0.42 & 0.95 & 5.70 \\
after inoculation & & & & & & & & \\
\hline
\end{tabular}

to normal. Clinical and hematological recovery coincided with an increase of the serum $\gamma$-globulins, but a decrease of hyperalpha-2 globulinemia occurred. One cat (exp.13) showed no signs of the disease.

Total protein values of plasma and sera of cats (exp. 10,11) showed no modifications that could be significantly related to the disease since there are important variations of these values in sera of cats without disease $[4,5,14]$. The ascitic fluid contained fewer proteins than plasma and serum. The albumin/globulin ratio was decreased in relation to hypergammaglobulinemia.

Serum transaminases determinations showed no significant variations in the course of the experimental disease, except for a high increase of the SGOT at the last stage of the disease in one cat (exp. 10) [1,20]. Electrophoreses of serum and plasma of animals with typical experimental disease showed important modifications in albumin and $\alpha$ - and $\beta$-globulins (table II; fig. 1,2). Fibrinogen increased as early as the 8th day after inoculation (fig. 1).

From the 4th day, a net and progressive increase of a narrow band of an $\alpha_{2}$-protein occurred (fig. 2). This protein has a slightly lighter molecular weight than the $7 \mathrm{~S}$ immunoglobulins, as its presence in the 4th fraction of elution on Sephadex G-200 suggests (fig. 3). Its glycoprotein nature appears after using PAS to analyze the electrophoreses of the same sera. We showed by electrophoresis of the serum after addition of hemoglobin that this $\alpha_{2}$ band corresponded to the haptoglobin. The increase of haptoglobulinemia was demonstrated by electrophoresis of serum sampled at different stages of the disease, after addition of hemoglobin in an amount slightly above that needed for the saturation of haptoglobin of the richest serum, taken before 


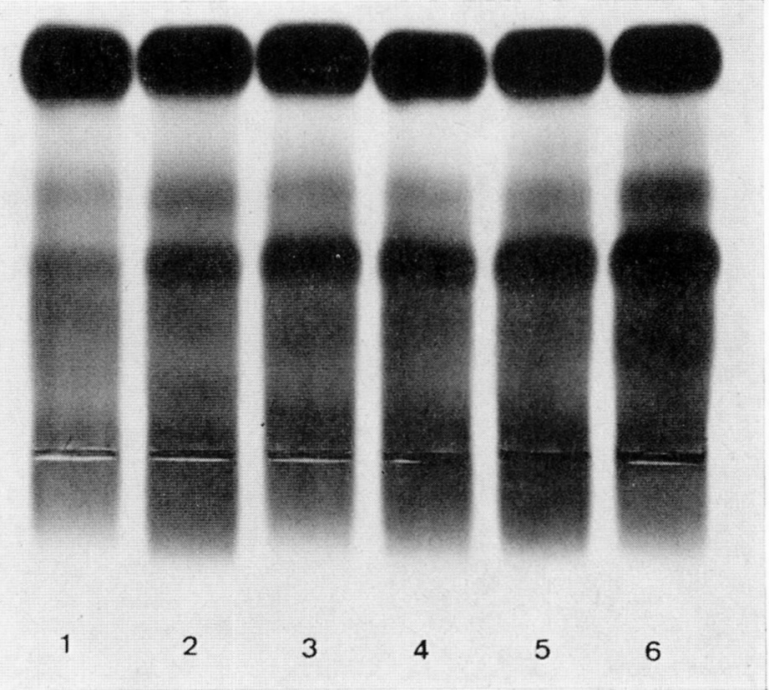

Fig. 1. Agarose gel electrophoresis. Cat exp. 10. Anode upwards. 1 = Plasma before inoculation; 2-6 = plasma from 4 th to 20 th day after inoculation.

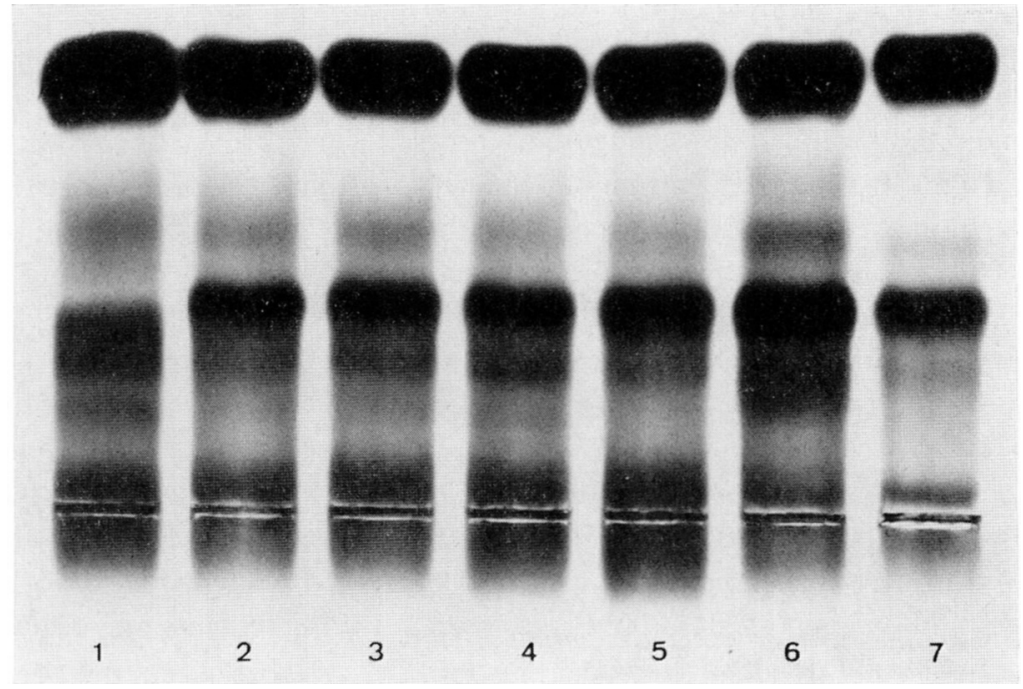

Fig. 2. Agarose gel electrophoresis. Cat exp. 10. Anode upwards. $1=$ Serum before inoculation; $2-6=$ sera from 4 th to 20 th day after inoculation; $7=$ ascitic fluid at the 20th day. 


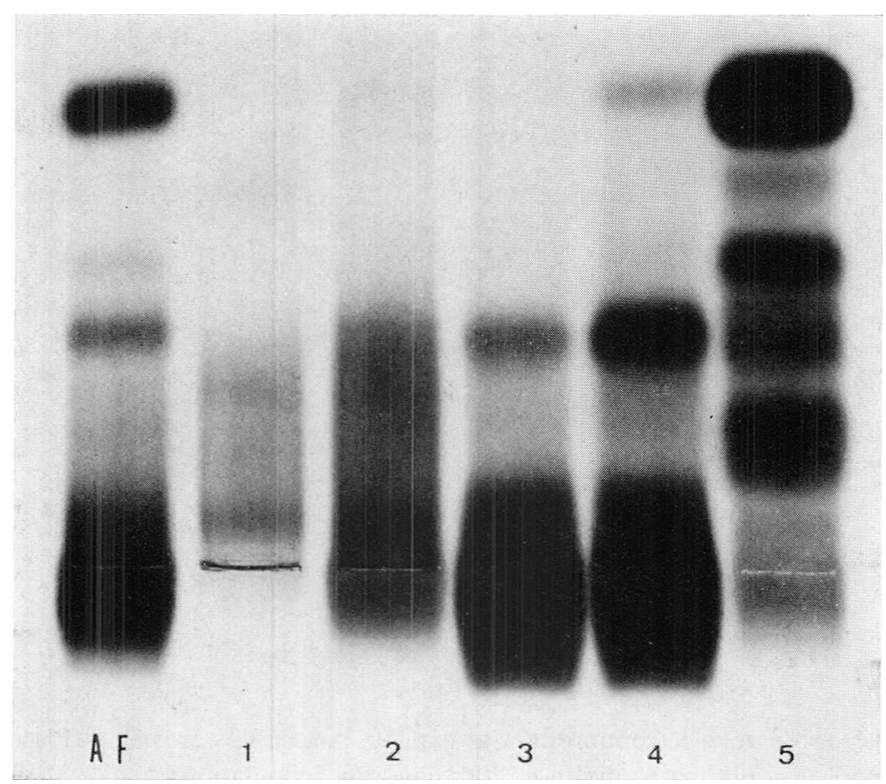

Fig. 3. Agarose gel electrophoresis. Eluted fractions one through five on Sephadex G-200 of ascitic fluid compared to whole ascitic fluid (AF). Anode upwards.

death. The decrease of the free hemoglobin band and the progressive development of the haptoglobin-hemoglobin complex band proved the evolutive character of the increasing serum value in haptoglobin (fig. 4). At the last stage of the disease, the saturation capacity of the serum in hemoglobin amounts to $10 \mathrm{mg} / \mathrm{ml}$, whereas the control serum is already saturated by $1.5 \mathrm{mg} / \mathrm{ml}$.

Electrophoreses of sera taken during the disease and stained by PAS or by amido-black (fig. 2) showed a steady increase of an $\alpha_{1}$-glycoprotein.

A steady increase of a band with $\beta_{1}$-mobility can be followed until the 20th day in serum and plasma (fig. 1,2); it was also found in the fifth eluted fraction of the ascitic fluid on Sephadex G-200; its molecular weight is therefore close to that of albumin. The rabbit serum against dog transferrine [23] showed in the serum of affected cats and in the fifth eluted fraction of the ascitic fluid on Sephadex G-200 a protein arc resulting from a cross-reaction between cat and dog transferrine.

The $\gamma$-globulins' electrophoretic pattern showed no change in the course of the experimental disease (fig. 2). The proteins of the ascitic fluid were similar in quantity to those of the serum (table II; fig. 2); the ascitic fluid did 


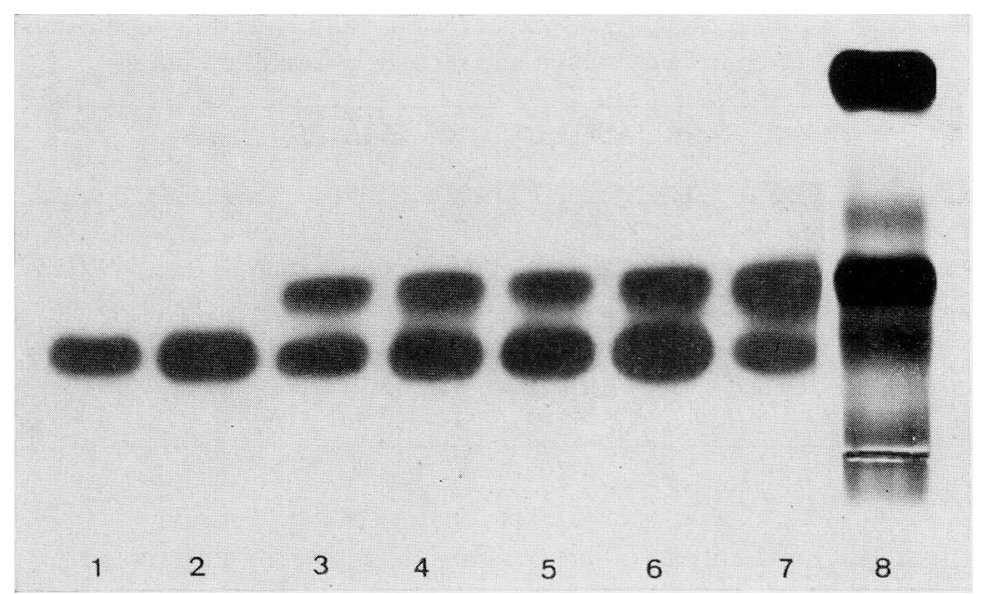

Fig. 4. Agarose gel electrophoresis. Cat exp. 10. Anode upwards. $1=$ Pure human hemoglobin $(7.5 \mathrm{mg} / \mathrm{ml}) ; 2-7=$ serum before inoculation and sera from 4 th to 20th day added with $10 \mathrm{mg} / \mathrm{ml}$ of pure hemoglobin and stained for hemoglobin; $8=$ serum at the 20 th day added with $10 \mathrm{mg} / \mathrm{ml}$ of pure hemoglobin and stained with amido-black.

not contain increased fibrinogen. Comparison between immunoelectrophoresis of serum and plasma taken at the beginning and at the end of the disease gave no further information.

\section{Natural Disease}

Clinical, hematological and anatomopathological aspects of the natural disease have been reported $[12,15,17,25,29,30]$. Its evolution ranges from a few weeks to several months. The main clinical findings are anorexia, weakness, often hyperthermia, and progressive abdominal distension. Other symptoms such as diarrhea and icterus exudative uveitis may be seen. Hematological examination shows a mild anemia and leukocytosis, with neutrophilia, lymphopenia and eosinopenia. The abdominal cavity is filled by an abundant and characteristic ascitic fluid containing fibrin tags; layers or small plaques of fibrinous material can be seen on the serosae, mainly at the surface of parenchyma. Pleural exudate is less frequently encountered. Principal microscopic lesions are fibrinous peritonitis. Fibrinous deposits are seen on the serosae of abdominal organs and contain many plasma cells, lymphocytes, histiocytes, neutrophils and cellular debris. Inflammatory reaction frequently involves underlying parenchyma of the liver and kidneys. Similar lesions may be seen on the thoracic serosae, meninges and in the 
Table III. Agarose gel electrophoreses; values for normal plasma and plasma and ascitic fluid taken from cat with a natural case, at end of evolution

\begin{tabular}{llrlrlrrr}
\hline Origin & Units & Albumin & $\alpha_{1}$ & \multicolumn{1}{c}{$\alpha_{2}$} & $\beta_{1}$ & $\beta_{2}$ & $\gamma$ & $\begin{array}{c}\text { Total } \\
\text { protein }\end{array}$ \\
\hline Plasma exp. 10 & $\%$ & 45.00 & 8.50 & 10.00 & 13.50 & 8.00 & 15.00 & 100 \\
before inoculation & $\mathrm{g} / \mathrm{dl}$ & 3.06 & 0.58 & 0.68 & 0.92 & 0.55 & 1.02 & 6.88 \\
Plasma NOC 08 at & $\%$ & 18.20 & 7.90 & 17.00 & 7.90 & 29.60 & 19.40 & 100 \\
end of evolution & $\mathrm{g} / \mathrm{dl}$ & 1.47 & 0.64 & 1.38 & 0.64 & 2.40 & 1.57 & 8.10 \\
Ascitic fluid NOC 08 & $\%$ & 19.10 & 7.35 & 17.65 & 7.36 & 20.59 & 27.95 & 100 \\
at end of evolution & $\mathrm{g} / \mathrm{dl}$ & 1.24 & 0.48 & 1.15 & 0.48 & 1.34 & 1.82 & 6.50 \\
\hline
\end{tabular}

ocular tissues. Germinative follicles of the spleen and mesenteric lymph nodes show an hyperplasia resulting from antigenic stimulation [15].

In five of our nine cases, the total protein in the ascitic fluid, taken a little before death, was more than $6 \mathrm{~g} / \mathrm{dl}$. In four cases, we have also been able to measure it in the serum; it was always richer than the ascitic fluid.

The electrophoreses performed with sera and ascitic fluids taken just before death show important modifications of the relative protein concentrations (table III; fig. 5). The albumin/globulin ratio was notably decreased in relation to both albumin decrease and globulin increase (table III).

Haptoglobin is found in large quantity, as in the experimental disease. The amount of $\gamma$-globulin is largely increased. The immunoelectrophoreses done with antisera against cat IgA, IgG and IgM show that most of these immunoglobulins are of the $\operatorname{IgG}$ class $[18,23]$. There is no change in the IgM or IgA classes. It may be inferred from the electrophoreses of ascitic fluids that the amount of $\mathrm{IgG}$ can reach up to $2 \mathrm{~g} / \mathrm{dl}$. The $\mathrm{IgG}$ of ascitic fluid is purifiable by ion-exchange chromatography; the second fraction of the step-wise separation contains pure IgG (fig. 6). The antiserum obtained by inoculation of this fraction into the rabbit appears to be specific of the cat $\mathrm{IgG}_{1}$ and $\mathrm{IgG}_{2}$, after absorption on the first fraction of elution of the ascitic fluid on Sephadex G-200, rich in IgM.

The following were seen after examination of the ascitic fluid stored at different temperatures: fluids frozen at $-20^{\circ} \mathrm{C}$ were completely coagulated; those stored at $4^{\circ} \mathrm{C}$ contained a clot that filled up a quarter of the volume; those at $20^{\circ} \mathrm{C}$ contained a small clot; the two tubes at $37^{\circ} \mathrm{C}$ had only very small clots, whereas those raised to $56^{\circ} \mathrm{C}$ were made cloudy, without coagulation. At $-20,4$ and $56^{\circ} \mathrm{C}$, there was no difference between the fluids of the same pair. After fluids were stored at 20 and $37^{\circ} \mathrm{C}$, a small clot appeared 


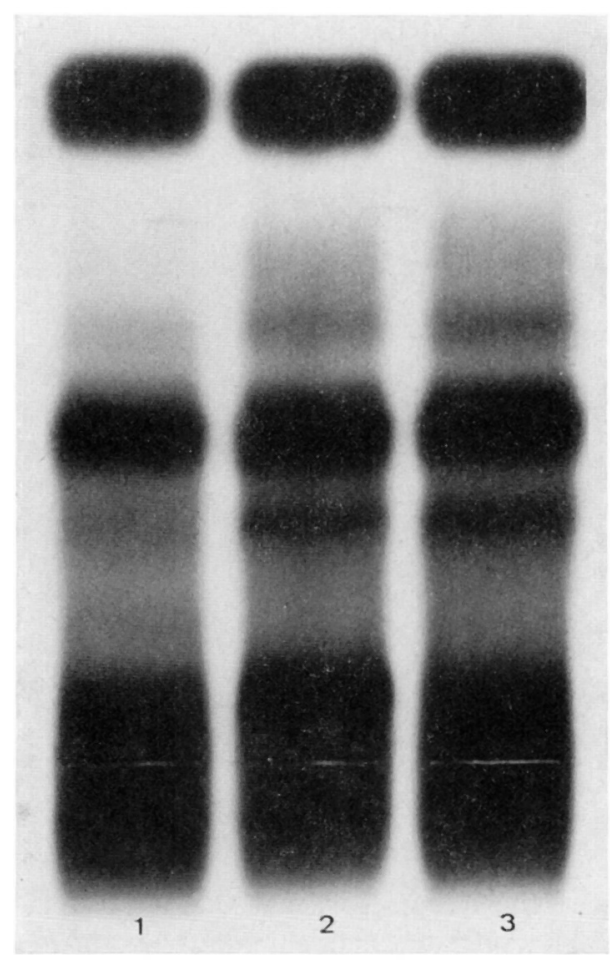

Fig. 5. Agarose gel electrophoresis. Ascitic fluid (1), plasma (2) and serum (3) from a cat with a naturally occurring case, at the end of evolution.

at the bottom of nonheparinized tubes but not in the heparinized ones. After clarification of the turbid fluids, further storage of all tubes at $-20^{\circ} \mathrm{C}$ for $16 \mathrm{~h}$ showed, after the fluids were reheated at $20^{\circ} \mathrm{C}$, that all were completely coagulated except those that had stayed previously at $56^{\circ} \mathrm{C}$. This stay at $56^{\circ} \mathrm{C}$ prevented further coagulation of the ascitic fluid. There was no difference between heparinized and nonheparinized tubes. After removing clots, electrophoresis showed no difference between the clotted fluids stored at $-20,4$, 20 and $37^{\circ} \mathrm{C}$; on the other hand, the fluids (heparinized or not) previously raised to $56^{\circ} \mathrm{C}$ had their electrophoretic pattern deeply modified (fig. 7).

\section{Discussion}

Feline infectious peritonitis seems to be of viral origin; the agent is probably a coronavirus not yet isolated $[26,27,31]$. Viral particles can be detected 


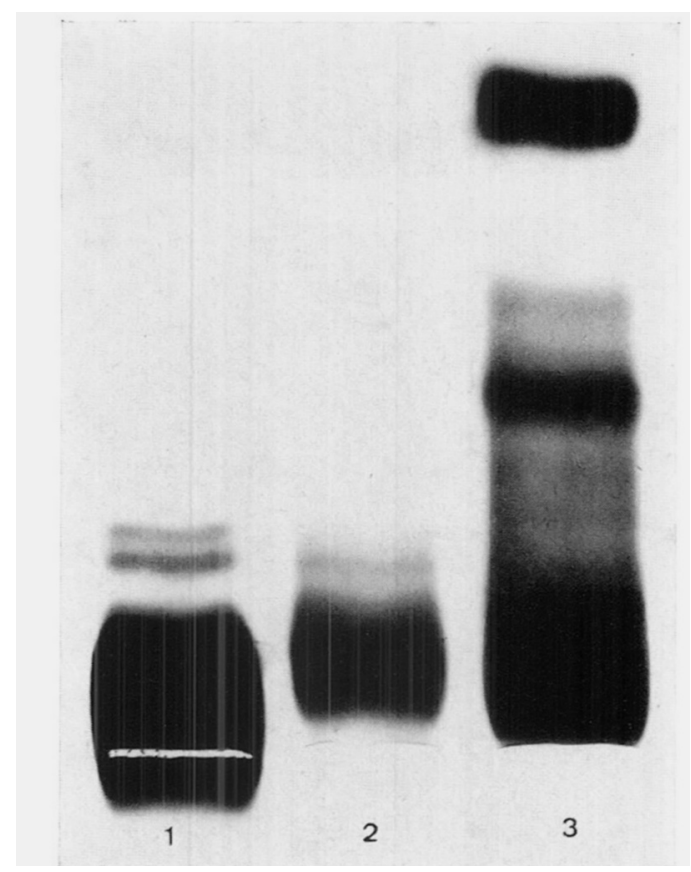

Fig. 6. Agarose gel electrophoresis. Fractions 1-3 of DEAE-cellulose chromatography of ascitic fluid taken from a cat with a naturally occurring case. Anode upwards.

by electron microscopy in mesothelial cells. Local and general inflammatory reactions induce the clinical pattern of the disease and accompany the cellular lesions. The intensity of these reactions is remarkable, and as soon as they have reached a clinically perceptible stage they are usually irreversible.

Experimental disease is characterized by rapid evolution and largely nonspecific clinical signs. Death ensues in about 15-20 days. The most significant lesions are necrosis of mesothelial cells and of subjacent parenchyma. The disease has a feature relevant to nonspecific and general reactions of inflammation: neutrophilia, hyperthermia and modifications of the plasmatic level of the so-called inflammatory proteins $[2,7,8,10,13,27]$. We have been able to characterize fibrinogen and haptoglobin on the basis of their biochemical properties. The work of OKOSHI et al. [14], the electrophoretic mobility, and the glycoprotein nature of the increased $\alpha_{1}$-protein suggest that it can be orosomucoid. The electrophoretic mobility of $\beta_{1}$-protein, its molecular weight, and the cross-reaction between this protein and dog transferrine 


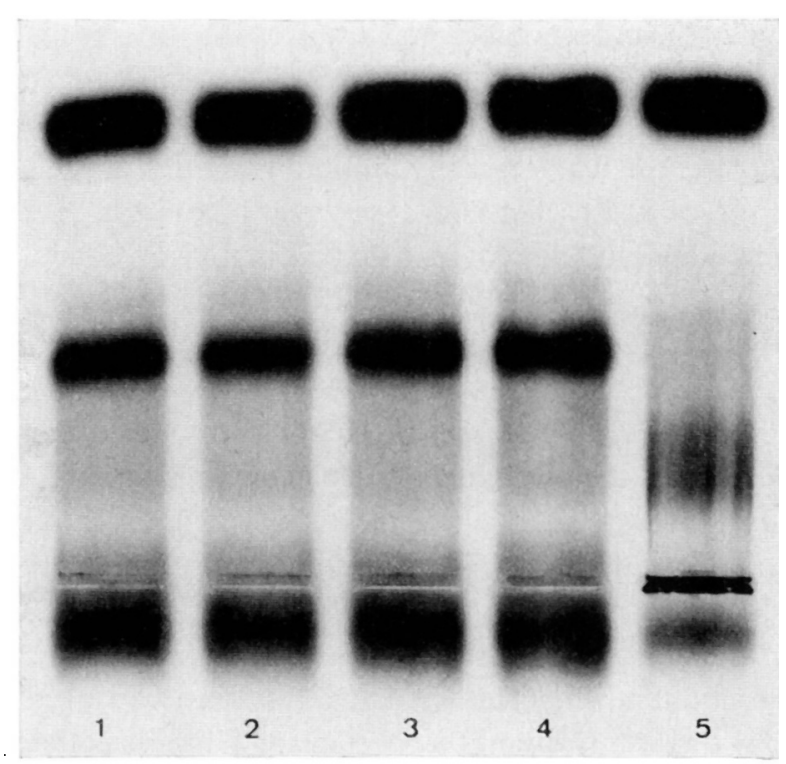

Fig. 7. Agarose gel electrophoresis. Ascitic fluid from a cat with a naturally occurring case after $16 \mathrm{~h}$ at $-20^{\circ} \mathrm{C} \mathrm{(1),} 4^{\circ} \mathrm{C} \mathrm{(2),} 20^{\circ} \mathrm{C} \mathrm{(3),} 37^{\circ} \mathrm{C} \mathrm{(4)} \mathrm{and} 56^{\circ} \mathrm{C}(5)$.

indicate, in agreement with OKоsHI et al. [14], that it is a transferrine. The mechanism of the modifications in level of plasma proteins still remains unexplained. It is known that the hepatic synthesis is influenced by various factors; some of them have been extracted from neutrophilic leukocytes and hepatic cells [13]. The accumulation of necrotic material in the central part of germinative follicles in lymphoid tissue, towards the end of experimental disease $[15,27]$, can be interpreted as a sign of antigenic stimulation; however, the rapid evolution of experimental disease explains the unincreased content of immunoglobulins.

In the natural disease, the evolution takes longer. Clinical signs are progressive wasting, ascites and sometimes thoracic, ocular or neurological manifestations. There is leukocytosis with neutrophilia, and a mild anemia. Serosae are overlayed with a fibrinous exudate infiltrated by numerous plasma cells, lymphocytes, and histiocytes relevant to a chronic inflammatory process. Histologic examination shows also antigenic stimulation in lymphoid tissue [15]; this lesion and plasma cell accumulation on the serosae are proof of the outcome of an immunological process. As in the experimental disease, some of the so-called inflammatory proteins are modified: fibri- 
nogen, haptoglobin, orosomucoid and transferrine are strongly increased; whereas the concentration of albumin decreases, probably because of its destruction in inflamed tissues and of disturbance in its hepatic synthesis [13]. At the last stage of the disease, many immunoglobulins of the IgG class are found in the serum and ascitic fluid. The great amount of ascitic fluid and its very high immunoglobulin content suggest that it is a source of cat polyclonal IgG.

The immunological processes in this disease will have to be studied further when the antigen becomes available.

Researchers have described the coagulability of the ascitic fluid when exposed to air. We ascertained that this coagulability occurs with plasma taken in natural as well in experimental cases on the 8th day of illness, whatever the anticoagulant used. The same observation applies to heparinized ascitic and pleural fluid.

Our preliminary observations on the coagulation of sera, plasma and pleural and ascitic fluid indicate that it operates in two stages. The first is precocious and quantitatively not important and concerns the transformation of fibrinogen into fibrin; the second, quantitatively much more important, is slower, independent of the action of usual anticoagulants, and influenced by temperature; it depends on factors destroyed after a period of $16 \mathrm{~h}$ at $56^{\circ} \mathrm{C}$.

\section{Acknowledgements}

The authors thank Dr. J.P. VAERMAN for advice and for supplying antisera.

\section{References}

1 Cornelius, C.E. and Kaneko, J. J.: Serum transaminase activities in cats with hepatic necrosis. J. Am. vet. med. Ass. 137: 62-66 (1960).

2 DARCY, D.A.: Response of a serum glycoprotein to tissue injury and necrosis. I. The response to necrosis, hyperplasia and tumour growth. Br. J. exp. Path. 45: 281-293 (1965).

3 Gorham, J. R. and Henson, J. B.: Basic principles of immunity in cats. J. Am. vet. med. Ass. 158: 846-856 (1971).

4 Groulade, P.: Aperçus sur l'électrophorèse des protéines sériques chez le chien et chez le chat. Bull. Ass. fr. Vét. Microbiol. Immunol. 12: 69-93 (1973).

5 Groulade, P.; Groulade, J., and Groslambert, P.: Age variations in the serum glycoproteins and lipoproteins in the normal cat. J. small Anim. Pract. 6: 331-361 (1965). 
6 Hardy, W.D. and Hurvitz, A. I.: Feline infectious peritonitis: experimental studies. J. Am. vet. med. Ass. 158: 994-1002 (1971).

7 Heim, W.G. and LANE, P.H.: Appearance of slow alpha-2 globulin during inflammatory response of the rat. Nature, London 5: 1077-1078 (1964).

8 Heiskell, C.L.; Carpenter, C. M.; Weimer, H. E., and Nakagawa, S.: Serum glycoproteins in infectious and inflammatory diseases. Ann. N. Y. Acad. Sci. 94: 183-209 (1961).

9 HirschrelD, J.: A simple method of determining haptoglobin groups in human sera by means of agar gel electrophoreses. Acta path. microbiol. scand. 47: 169-172 (1959).

10 Howard, E. B. and KenYon, A. J.: Canine mastocytoma: altered alpha globulin distribution. Am. J. vet. Res. 26: 1132-1137 (1965).

11 Jones, B. R. and HogG, G.G.: Feline infectious peritonitis. Aust. vet. J. 50: 398-402 (1974).

12 Konishi, S.; Takahashi, E., and Ogata, M.: Studies on feline infectious peritonitis (FIP). I. Occurrence and experimental transmission of the disease in Japan. Jap. J. vet. Sci. 33: 327-333 (1971).

13 Masson, P. L.: Molecular basis of inflammation. Ricerca 2: 389-426 (1972).

14 Oкоsнi, S. ; Tomoda, I., and Makimura, S.: Analysis of normal cat serum by immunoelectrophoreses. Jap. J. vet. Sci. 29: 337-345 (1968).

15 Pastoret, P.P.; Gouffaux, M., and Henroteaux, M.: Occurrence and experimental transmission of feline infectious peritonitis in Belgium. Annls Méd. vét. 118:479-492 (1974).

16 Potkay, S.; Bacher, J.D., and Pitts, T.W.: Feline infectious peritonitis in a closed breeding colony. Lab. anim. Sci. 24: 279-289 (1974).

17 Robison, R. L.; Holzworth, J., and Gilmore, C. E. : Naturally occurring feline infectious peritonitis: signs and clinical diagnosis. J. Am. vet. med. Ass. I58: 981-986 (1971).

18 Schultz, R.D.; DunCaN, J.R., and Gillespie, J.H.: Feline immunoglobulins. Infec. Immunity 9: 391-393 (1974).

19 Sigma Chemical Co.: The colorimetric determination of glutamic-oxaloacetic and glutamic-pyruvic transaminase at $490-520 \mathrm{~nm}$ in serum or other fluids. Sigma Tech. Bull. 505: 1-12 (1967).

20 Stunzi, H. und Grevel, V.: Die ansteckende fibrinöse Peritonitis der Katze. Vorläufige Mitteilung über die ersten spontanen Fälle in der Schweiz. Schweizer Arch. Tierheilk. 115: 579-586 (1973).

21 Tuch, K.; Witte, K.H. und Wuller, H.: Feststellung der felinen infektiösen Peritonitis (FIP) bei Hauskatzen und Leoparden in Deutschland. Zentbl. VetMed. B 21: 426-441 (1974).

22 Uriel, J. et Grabar, P.: Emploi de colorants dans l'analyse électrophorétique et immunoélectrophorétique en milieu gélifié. Annls Inst. Pasteur, Paris 90: 427-440 (1956).

23 Vaerman, J.P.: Studies on IgA immunoglobulins in man and animals. Thèse déposée en vue de l'obtention du grade d'agrégé de l'enseignement supérieur, Université de Louvain, Louvain, 1970.

24 Vaerman, J.P.; Heremans, J.F., and Kerckhoven, G. Van: Identification of IgA in several mammalian species. J. Immun. 103: 1421-1423 (1969). 
25 Ward, B. C. and Pederson, N.: Infectious peritonitis in cats. J. Am. vet. med. Ass. 154: 26-35 (1969).

26 WARD, J. M.: Morphogenesis of a virus in cats with experimental feline infectious peritonitis. Virology 41: 191-194 (1970).

27 Ward, J.M.; GribBle, D.H., and Dungworth, D.L.: Feline infectious peritonitis: evidence for its multiphasic nature. Am. J. vet. Res. 35: 1271-1275 (1974).

28 Watson, A.D. J.; HuXtable, C.R.R., and BenNetr, A. M.: Feline infectious peritonitis. Aust. vet. J. 50: 393-397 (1974).

29 Wolfe, L. G. and Griesemer, R. A.: Feline infectious peritonitis. Pathol. Vet. 3: 255270 (1966).

30 Wolfe, L.G. and Griesemer, R.A.: Feline infectious peritonitis: review of gross and histopathologic lesions. J. Am. vet. med. Ass. 158: 987-993 (1971).

31 Zook, B.C.; King, N.W.; RoBinson, R.L., and McCombs, H.L.: Ultrastructural evidence for the viral etiology of feline infectious peritonitis. Pathol. Vet. 5: 91-95 (1968).

Dr M. Gouffaux, Department of Pathology, Faculty of Veterinary Medicine, 45, rue des Vétérinaires, B-1070 Bruxelles (Belgium) 